\title{
Gender-based discrimination during appointments, promotions and remuneration: Views of South African managers
}

\author{
by Renier Steyn ${ }^{*}$ and Leon Jackson ${ }^{* *}$
}

\begin{abstract}
Managers are key in the appointment, promotion and remuneration of staff, and as such, they are actively involved when discrimination occurs in the workplace. This also applies to gender-based discrimination. The objective of the current research was to identify the points in human resource processes where genderbased discrimination most often occurs, as seen and experienced by managers. Interviews were conducted with 75 managers from 15 organisations. Questions were posed about the prevalence and nature of gender discrimination during different human resource processes. The responses were categorised and the overall inter-observer reliability was .88. Most cases of gender-based discrimination occur during promotion processes, and this generally involves profemale discrimination. Pro-male discrimination occurs at appointment level and is often due to the inherent requirements of the job. Discrimination at remuneration level seems to favour men, allowing them to receive higher salaries than women at the same organisational level. Discrimination occurs in structured (e.g. job descriptions) as well as less structured (e.g. decision-making after interviews) phases of human resource processes. It can be concluded that gender-based discrimination still occurs and that both genders are affected negatively. It is recommended that managers be vigilant in order to avoid these discriminatory tendencies.
\end{abstract}

Key words: gender, discrimination, appointment, promotion, remuneration, management

\section{Introduction}

Gender-based discrimination is against the spirit and the letter of the South African Constitution. It is stated in the Constitution that "the state may not unfairly discriminate directly or indirectly against anyone on one or more grounds, including race, gender, sex, pregnancy, marital status, ethnic or social origin, colour, sexual orientation, age, disability, religion, conscience, belief, culture, language and birth" (Republic of South Africa 1996: s $9(3)$ ). It is, however, not only the state that is prohibited from practising unfair discrimination; South African labour legislation also prohibits such actions by employers. The Labour Relations Act (Republic of South Africa 1995: s 2(1)(a))

Prof R Steyn is a Professor of Leadership and Human Resources Management in the Graduate School of Business Leadership at the University of South Africa.

Prof LTB Jackson is an Associate Professor of Change Management and Diversity Management in the Potchefstroom Business School at North-West University. 
specifically states that "unfair discrimination is prohibited, either directly or indirectly, against an employee on any arbitrary ground, including, but not limited to race, gender, sex, ethnic or social origin, colour, sexual orientation, age, disability, religion, conscience, belief, political opinion, culture, language, marital status or family responsibility".

The fact that section $1(\mathrm{~b})$ of the Constitution specifically states that the Republic of South Africa is founded on certain values, including non-racialism and non-sexism (Republic of South Africa 1996), and the fact that the Constitution also makes provision for a Commission for Gender Equality, which "has the power, as regulated by national legislation, necessary to perform its functions, including the power to monitor, investigate, research, educate, lobby, advise and report on issues concerning gender equality" (Republic of South Africa 1996: s 187(2)) suggests that gender-based discrimination may be a problem in South Africa or may have been one in the past. The legislative process of dealing with gender equality is continuing, as the Women Empowerment and Gender Equality Bill, which could be implemented as early as 2015, aims to enforce gender equality and will allow the state to fine and/or imprison executive heads who contravene the Act (see Republic of South Africa 2013).

The reports of studies on gender-based discrimination in South Africa also affirm that gender-based discrimination may still be a problem. Some of these reports focus and report on female underrepresentation in the workplace in general (Floro \& Komatsu 2011; Mathur-Helm 2005; Serumaga-Zake \& Naudé 2003), while many report on female underrepresentation in senior positions (Kahn 2008; Mathur-Helm 2006; Mello \& Phago 2007). Senior positions usually carry higher salaries, and several articles focus on gender differences in remuneration amongst those who hold senior positions (Grun 2004; Hinks 2002; Walters \& Le Roux 2008). Many articles discuss the barriers which women encounter in the workplace and which prevent them from optimising their potential (April, Dreyer \& Blass 2007; Booysen 2007; Johnson \& Mathur-Helm 2011; Niemann 2002) and from obtaining senior positions and higher remuneration. Certain official reports, such as the latest employment equity report (Employment Equity Commission 2013), as well as information provided by the Commission for Gender Equality (Anon 2012), suggest that the existence of gender discrimination, and particularly discrimination against women, is a significant problem.

The people responsible for gender-based discrimination are employers, as suggested in the legislation, which refers to the duties of employers (see Basic Conditions of Employment Act 1997). The results of empirical studies also suggest that employers discriminate against female employees (see Ncayiyana 2011; Pretorius et al 2002; Stone \& Coetzee 2005). This disproportionate distribution of power and suppression of certain groups is clearly explained in critical theory and in the writings of Marxist thinkers. It may therefore be necessary to focus on employers and their actions in order to pinpoint where discrimination occurs. It is important to focus on the actions of employers as discrimination is often defined in the context of a specific action. Grogan (2007) defines discrimination (in general) as the action where some are afforded benefits and others are denied access thereto, while Cascio (2010) introduces a group element in stating that discrimination entails a group of individuals being given preferential treatment over others. With regard to gender-based discrimination, Channer, Abbassi and Ujan (2011) state that discrimination entails conferring an unfair advantage or disadvantage on members of a particular gender in comparison with members of the other gender. It is therefore through actions or activities that employers discriminate against women in the workplace. 
The type and frequency of discriminatory actions performed by employers, as reported by employers themselves, have not previously been recorded. The aim of the research was to do that, namely to report on gender-based discrimination from the perspective of a decision maker (employer/manager). This was done firstly by identifying the human resource processes (appointment, promotion, remuneration) during which gender-based discrimination most often takes place, and then by specifying the stage of the process at which this most frequently occurs. This knowledge may encourage human resources practitioners, and managers as well, to avoid engaging in practices which are discriminatory. The findings are based on an analysis of interviews with 75 managers within the domains of human resources and operations.

\section{Literature review}

The aim of the literature review was to compile lists of steps (actions) in human resource processes where gender-based discrimination could occur. The literature review also attempted to show how gender-based discrimination may manifest during these steps. Three processes, namely appointments, promotions and remuneration, were selected and will be discussed with reference to the steps of which they consist. These three processes were selected because of the prominence they enjoy in employment equity legislation as well as in the literature on the subject.

\subsection{Steps in human resource processes}

Regarding the appointment process, different authors suggest very similar steps for the completion of this task. For example, Mondy (2012) suggests seven steps, namely preliminary screening, reviewing of applications and résumés, applying selection tests, conducting employment interviews, pre-employment screening, making a selection decision, and medical examination. Ivancevich (2010) mentions six steps: preliminary screening, interviewing, employment tests, reference checks and recommendations, selection decision, and physical examination. In their description of the selection process, Bohlander and Snell (2013) distinguish between selection carried out by the human resources department and that done by line managers. Their process consists of eight steps: completion of an application, initial interview, employment testing, background investigation, preliminary selection in the human resources department, supervisor/team interview, medical examination and drug testing, and the hiring decision. The importance of having job-specific information (job analysis) available before starting the process is emphasised by Nel et al (2008). Swanepoel, Erasmus and Schenk (2008) suggest that it is necessary to determine the exact needs before starting the process. Another important consideration is the matter of organisational policies and knowledge of such policies (Stone \& Stone-Romero 2006). The steps suggested by other authors, such as Cascio (2010), Dessler (2011) and Noe, Hollenbeck, Gergart and Wright (2008) are very similar to those already mentioned and contribute little more to an understanding of the appointment process.

Given the aforementioned, the following steps in the process could be deemed to be generically representative of the appointment process:

- job analysis/post description;

- advertising of post;

- screening of applicants (e.g. psychometric tests and medical examinations);

- interviews with applicants; 
- decisions further to interviews;

- salary offer;

- induction of employee (orientation); and

- placement of employee.

The steps in the promotion process, as described by Swanepoel et al (2008) and Cascio (2010), are similar to the steps in the appointment process. Building on the literature with regard to appointments as well as on personal insights and experience, the authors compiled a list of possible steps in the promotion process. The promotion process can be seen as a nine-step process:

- job analysis/post description;

- access to appropriate development and training;

- performance appraisal of employee;

- advertising of post;

- screening of applicants;

- interviews with applicants;

- decisions following interviews;

- salary offer; and

- induction of employee.

During the appointment and promotion processes, remuneration is often open to discussion. Swanepoel et al (2008) and Cascio (2010) are in agreement that four tasks need to be completed in determining remuneration, namely job analysis, job evaluation, pay surveys and pay structuring. These tasks seem to be central to the remuneration process, although some authors' lists are more comprehensive. According to Nel et al (2008) the remuneration process consists of the following six steps: conducting a job analysis, identifying compensable factors, developing a job hierarchy, constructing job grades, carrying out a compensation survey, and lastly, establishing final pay policy. Lim, Mathis and Jackson (2010) describe similar first steps, but add performancebased pay as well as operational need, as additional factors to be considered. Lim et al (2010) list the following tasks: job analysis (job descriptions and job specifications), pay surveys and job evaluation, pay structure (pay policies), individual pay (performance appraisal), implementation, communication and monitoring. Given the aforementioned, the following list of generic steps in the remuneration process can be abstracted:

- job analysis - identify and describe characteristics of the job;

- job evaluation - determine the value of the job compared to other positions;

- pay structuring - allocate monetary value to jobs based on job evaluation and market rates;

- performance appraisals - effective assessment of individual performance; and

- decision-making practices - pay-related decisions.

These lists could be used to identify the points in the human resource processes where discrimination could occur. Such an approach, where the focus is on generic activities, is compatible with the universalistic human resource perspective, based on the pioneering work of Pfeffer $(1994 ; 1995 ; 1998)$. Pfeffer found that organisational performance depends on common human resource practices, and that this is true regardless of the industry or strategy pursued. His list of practices includes (fair) selective hiring and compensation based on work-related performance. Once a company is able to engage fully in these best practices, performance will follow, according to Pfeffer. The aim of the current research was to identify practices that lead to gender discrimination, thus undermining fair selective hiring and compensation based on work-related performance. 


\subsection{Manifestations of gender-based discrimination}

The literature consulted indicated that discrimination often occurs during specific steps in the human resources processes.

\subsubsection{Job analysis/post description}

The first occurrence of discrimination may be during the job analysis or the compilation of the post description. The results of the job analysis should reflect the job requirements and should serve as a basis for specifying the profile of the ideal incumbent. Bias may be introduced here because conceptions of the ideal incumbent are typically affected by the beliefs of the dominant group in the organisation. If biases are introduced at this early stage, this will affect the subsequent steps in the process (Stone \& Stone-Romero 2006). Of particular concern is the question of occupational "sex types". Adherence to this concept can result in post descriptions based on the perceived masculinity and femininity associated with the post (Hareli, Klang \& Hess 2008). A related issue is the use of wording that could exclude men or women from certain positions. An example of this would be referring to prospective employees as "salesladies" rather than "salespeople". This may intentionally or unintentionally flaw processes that follow such descriptions (Basim, Sesen \& Sesen 2007). Basim et al (2007) also appeal for clear and unbiased criteria and guidelines related to job descriptions in order to minimise the possibility of discrimination.

\subsubsection{Recruitment strategies}

Bias or discrimination can be an issue if recruitment strategies or materials lead potential applicants to believe that they may not suit the organisation (Stone \& StoneRomero 2006) or the job. In this regard, Swanepoel et al (2008) argue that the inherent requirements of the job must be clearly spelt out and that the prerequisites or qualifications attached to the job should be justifiable.

Another form of discrimination is where recruitment strategies leave potential applicants unaware that jobs have become available, thus precluding them from applying (Bezuidenhout, Garbers \& Potgieter 2007; Dessler 2011; Stone \& StoneRomero 2006; Swanepoel et al 2008). This may happen when advertisements are placed in such a way that people from a particular group are excluded or disproportionately represented (Dessler 2011; Swanepoel et al 2008). Discrimination may also occur where job descriptions use potentially discriminatory language, such as the word "she" when advertising secretarial positions or "he" when advertising the post of a production manager (Basim et al 2007; Swanepoel et al 2008).

\subsubsection{Screening}

Assessors use subjective and objective techniques as screening devices to eliminate applicants who do not meet one or more of the relevant specifications for the job (Grobler, Wärnich, Carrell, Elbert \& Hatfield 2011). It is, however, not only job-related information that influences assessors during screening. Other information on employment forms, such as marital status, race, age, experience and reasons for leaving previous organisations can be used to discriminate against a candidate (Basim et al 2007). Referring to the latter, information on the application form may disadvantage female employees, as females often have long periods of unemployment as a result of family responsibilities, and employers tend to discriminate against people who have been unemployed for prolonged periods (Mathis \& Jackson 2003).

To promote an objective and non-discriminatory process, shortlisting should ideally be carried out by the interview panel, or at least by one member of the panel and 
another appropriate person (Armstrong 2009). This ensures that a number of people assess a candidate and individual opinions or prejudices do not dominate the process (Cascio \& Agiunis 2011). This is important within the context of gender discrimination, as Welle and Heilman (2005) report that even when the actual qualifications of men and women are equivalent, men are viewed as having higher performance ability, are expected to perform better, and are therefore favoured over women in the selection process for male gender-typed jobs. Here it is important to note that the traits women "supposedly possess tend to be viewed as less appropriate for high-status positions than the traits supposedly possessed by men" (Baron, Branscombe \& Byrne 2009:192). Stone and Stone-Romero (2006) further warn that with limited material available to make initial judgements about the applicant's suitability, decision makers are likely to base their suitability judgements on stereotypes, and this may lead to negative outcomes for applicants who are the targets of bias.

\subsubsection{Psychometric assessments}

Karsten (2006) states that the use of tests may improve the reliability and validity of the outcome of selection decisions. Employment tests must be validated for the specific jobs they are being used for, and users of tests should avoid using very general tests for many different jobs without taking specific validity into consideration (Grobler et al 2011). Apart from validity, the reliability of the tests, or the consistency of the measure, is important (Cascio 2010; Grobler et al 2011; Nel et al 2008). However, tests may be valid and reliable, but may still be biased against a particular group. Bias refers to a situation where the score on a test, or an item in a test, is a function of group membership, rather than the individual's attitude or ability (Meiring, Van de Vijver, Rothman \& Barrick 2005). Karsten (2006) affirms this and states that an examination of the selection procedures may reveal that some groups are disproportionately advantaged or disadvantaged because of the tools used.

The use of psychometric tests for screening is often regulated by legislation (see Bohlander \& Snell 2013; Cascio 2010; Gómez-Mejía, Balkin \& Cardy 2007; Grobler et al 2011; Nel et al 2008). Within the South African context, section 8 of the Employment Equity Act 55 of 1998 is applicable. The act states:

Psychometric testing and other similar assessments of an employee are prohibited unless the test or assessment being used -

a) has been scientifically shown to be valid and reliable;

b) can be applied fairly to all employees; and

c) is not biased against any employee or group.

$\mathrm{Nel}$ et al (2008) emphasise that tests should only be used under these legislatively stipulated conditions. If used correctly, psychometric measures may be an effective means of minimising unfair discrimination and subjectivity during screening.

\subsubsection{Interviews}

Interviews aim to establish whether the applicant has the ability to perform the job, how motivated the individual is to succeed at the job, and whether he or she will match the organisation's needs (Grobler et al 2011). Interviewing needs to be carried out in such a way that all candidates are treated equally and fairly (Stredwick 2005). Interviews, like the other steps, can fall short in reliability and validity (Grobler et al 2011). Adequate preparation and the use of a carefully structured interview system offer the best protection against claims of discrimination (Cascio \& Agiunis 2011; Stredwick 2005). 
Intrusive questions, even when well structured, can have connotations of unfair discrimination (Stredwick 2005; Swanepoel et al 2008). Metcalf and Rolfe (2009) state that women are often asked questions about family situations or commitments in interviews, which raises unfair discrimination issues. Certain types of interviews, such as stress tolerance interviews, may be seen as intrusive, and may alienate certain candidates (Fisher, Schoenfeldt \& Shaw 2006). This applies particularly to women, who do not necessarily enjoy situations of equal status (Konrad, Ritchie, Lieb \& Corrigall 2000), but who tend to rate communal factors as more important in the workplace than men do (Frame, Roberto, Schwab \& Harris 2010).

Returning to the matter of structure, unstructured interviews are seen as a potential risk and can be perceived as an unfair selection tool (Cascio \& Agiunis 2011; Swanepoel et al 2008). Unstructured interviews can discriminate against candidates as questions are not used consistently, which reduces their reliability and validity (Fisher et al 2006). According to Bradley and Healy (2008), the content of the interview is the critical aspect that determines its validity. They warn against questions that may create the impression that individuals from certain groups will be discriminated against, or that the interview may reflect a preference for members of another group.

Even benevolent sexism has a negative effect on interview outcomes for women (Good \& Rudman 2009). It is interesting to note that male decision makers often prefer female partners to men, as they believe that women are more trustworthy than men (Slonim 2004). Grobler et al (2011) highlight this dilemma and state that the total evaluation process is at risk where interviewers hire whomever they are comfortable with. According to Swanepoel et al (2008), the interview is not necessarily the best predictor as females are often rated lower than men in interviews for jobs that depict traditional male sex roles. They suggest that gender prejudices and stereotyping cannot be corrected because they are innate, and this embeddedness tends to blur all information. This is in contrast to the views of Yukl (2010), who believes that the use of trained assessors for selection and promotion decisions limits the biases caused by racial and gender stereotypes.

\subsubsection{Decision making}

The decisions that follow interviews may also result in gender-based discrimination. Many jobs are perceived as gendered, that is, men and women are perceived as likely to perform differently in a given job. Consequently, hiring decisions are partially based on whether the job in question is considered more suitable for men or for women, thereby leading to gender-based discrimination in hiring decisions (Burke \& Vinnicombe 2005). In order to make the hiring process more effective, Ocon (2006) suggests that employers should follow a stepwise process embedded in policy when accepting and reviewing applications. The entire hiring process should focus on recording and preserving evidence of non-discrimination. Decisions taken after due process are less discriminatory than where due process was not followed (Slonim 2004). The use of a combination of selection tools can improve the chances of making the right selection (Karsten 2006). Cascio and Agiunis (2011) urge decision makers to follow a mechanical or statistical route when they combine data from different sources, as relying on judgement often fails to produce valid and reliable outcomes. It is important to note within this context that in terms of the Employment Equity Act of 1998 affirmative action policies favour women in South Africa, and will continue to do so in the foreseeable future if the Women Empowerment and Gender Equality Bill of 2013 is signed into law. 


\subsubsection{Remuneration}

Employees expect to be treated fairly and equitably. This implies that there should be a balance between the contribution an individual makes to a job and the returns the individual receives from it (Fisher et al 2006). It is, however, not a requirement that the equal pay concept for a job must be applied if disparities ensue from seniority or performance (Fisher et al 2006). This is by no means a simple matter and processes of which people are not fully aware may play a role here. Gender, for example, is a category which is always present in all societies, and attributes associated with males and females shape the way the individual's skills and attributes are perceived. Men are thought to possess agentic traits, such as being decisive and task-oriented (see Barry, Child \& Bacon 1959; Pratto 1996; Schwartz \& Rubel 2005), while women are thought to possess communal attributes, such as nurturance and being more relationship-oriented (see Rossi \& Rossi 1990; Tamres, Janicki \& Helgenson 2002; Taylor 2002). When the gender stereotypes of an individual match the gender type of the job, that individual may be perceived as possessing the attributes required to perform well in that job. This process works against women and in favour of men in employment settings that potentially have the most rewards to offer (Mathis \& Jackson 2003), as most highpaying jobs traditionally favour masculine traits. This situation is aggravated by what Naidu (1997) refers to as "structural" or "institutional" discrimination. This stems from the organisational norms, rules and procedures used to determine the allocation of positions and benefits. These elements have generally been designed, whether deliberately or unreflectively, around the behaviour patterns and attributes of the historically dominant group. This group is traditionally regarded as consisting of males, and this perception may lead to discrimination against females.

Nel et al (2008) argue that where differentiation in remuneration exists, this should be permissible only in as far as it pertains to the level, status and content of the job, or the level of performance of the incumbent (as evaluated by generally acceptable means), and not by gender. This, however, does not seem to be the norm, as Metcalf and Rolfe (2009) argue that gender and pay discrimination are prevalent throughout all pay structures, including basic pay, performance assessment and total earnings, and they state that employment policies and practices are contributory factors to these pay discrepancies. Nel et al (2008) suggest the use of formal processes with clear guidelines that advocate the principle of equal pay for equal work. Nel et al (2008) also contend that the methods of evaluating jobs and job grading should accord with accepted standards and that these systems should be published and available for inspection by all employees. The same authors recommend that employers should consider including a code on equal remuneration in their conditions of employment as an assurance of fair remuneration practice.

To conclude, Gandhi (2010) reports that research across the decades has shown that women are at a disadvantage compared to men in all aspects of employment, from hiring and promotion to pay aspects. Metcalf and Rolfe (2009) affirm this and state that recruitment and selection processes contribute, through discriminatory practices, to placing women in categories, which impedes promotion, training and career advancement.

\section{Method}

This section discussed the way in which the research was conducted. 


\subsection{Respondents}

The respondents in this study were managers who had a direct influence on the appointment, promotion and remuneration of employees. Only managers overseeing relatively large groups of employees were involved. In order to qualify for inclusion in the study, the organisations had to have a diverse workforce of at least 30 male and 30 female employees, all of whom were willing to participate in the study. The organisations that were approached were those to which students enrolled for the Master of Business Leadership programme at the Unisa Graduate School of Business Leadership had access, primarily via their own employment in the said organisations. It was therefore a convenience sample (Rosnow \& Rosenthal 2008). The students conducted interviews with the most senior human resources managers as well as with four other managers who were directly involved in the appointment and promotion of employees in the organisation. In all, managers from 15 organisations were interviewed. Data was therefore collected from 75 managers. The managers were from mining companies (25 managers), the services industry (15 from financial services and 5 from tourism), government (10 from national government, 5 from provincial government and 5 from local government), as well as the small manufacturing segment (10 managers).

\subsection{Approach and procedure}

Structured interviews were used to collect the data at a specific time. This indicates a cross-sectional design, which was found to be suitable for describing the population (Shaughnessy, Zechmeister \& Zechmeister 2009). Managers were asked questions on discriminatory practices during appointments, promotions and decisions on remuneration, as well as on policies in this regard.

Managers were then asked the following four questions regarding appointments:

- "Do you believe that there is discrimination, in favour of or against women, in terms of the appointment of women at this organisation?" If they indicated that discrimination in favour of or against women existed, they were asked to explain what form it took. This was captured verbatim.

- Managers were then requested to look at a chart depicting a generic appointment process (capturing the steps of the appointment process as described in the literature review), and asked the following question: "Does discrimination against women occur in any of these steps?" This question was posed only to those managers who responded affirmatively to the first question. Managers were asked to indicate in which step discrimination occurred.

- Managers were then asked: "Are there any formal policies in this organisation that suggest that women should be given preferential treatment with regard to appointments in the organisation?"

- Lastly, a question on informal policies was put to the managers: "Are there any unwritten instructions in this organisation that suggest that women should be given preferential treatment with regard to appointments in the organisation?"

This concluded the questioning with regard to appointments.

Exactly the same line of questioning, using the format described above, was followed with regard to promotions and with reference to remuneration aspects.

Those managers who worked in big organisations were reminded that they should focus their comments on the section of the organisation of which they had direct knowledge, and should not focus on the organisation as a whole, of which they might only have limited knowledge. 
All the managers' responses were recorded verbatim. The content of the responses to the interview questions was analysed (see section 3.3), which is indicative of a qualitative approach. However, the frequency of the responses was also counted, thereby introducing an element of quantitative data analysis (Terre Blanche, Durrheim \& Painter 2009).

\subsection{Data analysis}

Content analysis (Terre Blanche et al 2009) was used to analyse the responses of the managers. The procedure used was firstly to read the full corpus of the narrative and then to categorise the narrative according to the coding guide. The coding was therefore done deductively, starting with predefined themes (as described in the literature review above) and matching the collected data with the themes (Terre Blanche et al 2009). To ensure that the findings were reliable, an independent observer was trained to use the coding system. To ensure the effectiveness of the coding scheme it was first tried out on a copy of the collected material. Where the researcher and the observer disagreed about the classification of a phrase, categories were defined in greater detail (see Shaughnessy et al 2009) to ensure that the categories were mutually exclusive and exhaustive (Shaughnessy et al 2009). This sharing of ideas between the observer and the trainer contributed to the trustworthiness of the findings (Glesne 2011). Inter-observer reliability was calculated as the ratio of the number of times the observers agreed about an allocation over the number of opportunities there were for agreement (Shaughnessy et al 2009). "Although there is no hard-and-fast percentage of agreement that defines low inter-observer reliability, researchers generally report estimates of reliability that exceed $85 \%$ " (Shaughnessy et al 2009:122). This value was taken as a general guideline in this research.

In reporting the findings, the frequency and the relative frequency were reported. The relative frequency is the ratio of the observations per category over the total number of observations (Shaughnessy et al 2009). The reported findings include some direct quotes from the interviews. Such quantification and verbatim reports contribute to the trustworthiness of the findings (Frost 2011).

\subsection{Ethical considerations}

Several ethical considerations were applicable to this study. The first issue was the possible exploitation of students as fieldworkers. Students benefitted from collecting the data, however, as they used the data in writing their own research reports. A possible second ethical concern was that students accessed respondents in the organisations where they worked, thus having undue influence over the respondents. This matter was partially addressed by the requirement that the chief executive officer or directorgeneral of the organisation concerned had to give permission to conduct the study (suggesting that the student did not have ultimate authority in the setting). Consent was also obtained from the respondents. In fact, some of the respondents were on a higher organisational level than the students, which provided them with an easy opportunity to withdraw from the study. The informed consent form also stated that participation was voluntary and all respondents had given written consent before becoming part of the study.

\section{Findings}

In all, 75 interviews with managers in 15 organisations were captured. The findings are presented separately in terms of appointments, promotions and remuneration. No 
biographical data on managers were collected, as collecting such data from small groups (with five members) would make the identification of such individuals likely and encroach on their rights to privacy and anonymity. Table 1 in this article therefore does not take the traditional form.

\subsection{Appointments}

The findings indicated that $24(32 \%)$ of the 75 managers interviewed gave an affirmative answer to the question: "Do you believe that there is discrimination, in favour of or against women, in terms of the appointment of women in this organisation?" Twenty-eight participants made statements explaining discrimination at appointment level. The contents of these explanations were analysed by the author as well as by the trained independent observer and the findings are captured in Table 1, in the column marked "volunteered responses". It was possible to categorise only 20 of the statements according to the pre-set grid. The balance of the statements (8) focused on an element that was not listed and related to human resource planning and strategy. Examples of these statements were:

- "The general environment in this company favours women" and, even more tellingly,

- "We have a focus ... in mining which gives women an edge ... in line with the mining regulations and mining charter and it is suggested that women should be given preferential treatment [sic]".

This theme is important as almost $29 \%$ of all volunteered responses related to it. It was possible to categorise the rest of the items according to the preset grid, and the interobserver reliability figure for the statements that were categorised was .80. Although the reported reliability is lower than the guideline set by Shaughnessy et al (2009), it is still relatively high at .80 , and the results regarding appointments are therefore reported.

Table 1

Areas of discrimination against women in the appointments process

\begin{tabular}{|l|c|c|c|c|}
\hline \multicolumn{1}{|c|}{ Themes } & \multicolumn{2}{c|}{ Volunteered responses } & \multicolumn{2}{c|}{ Endorsed themes } \\
\hline Job analysis/post description & Count & $\begin{array}{c}\text { Relative } \\
\text { frequency }\end{array}$ & Count & $\begin{array}{c}\text { Relative } \\
\text { frequency }\end{array}$ \\
\hline Advertising of post & $.5 ; 1 ; 1 ; 1 ; 1 ; .5 ; 1 ; 1 ; 1 ; .5$ & .43 & 9 & .12 \\
\hline Screening of applicants & & & 6 & .08 \\
\hline Interviews with applicants & $.5 ; 1 ; 1$ & .13 & 14 & .19 \\
\hline Decisions further to interviews & 1 & .05 & 11 & .15 \\
\hline Salary offers & $.5 ; .5 ; 1 ; 1$ & .15 & 21 & .28 \\
\hline Induction of employees & & & 3 & .04 \\
\hline Placement of employees & & & 1 & .01 \\
\hline Total & $.5 ; 1 ; 1 ; 1 ; 1 ; .5$ & .25 & 10 & .13 \\
\hline
\end{tabular}

\# A score of .5 indicates that one observer selected the theme while the other person favoured a different theme. A score of 1 indicates that the observers were in agreement with the allocation of the themes.

The most frequently volunteered theme was discrimination during the job description (43\% of all volunteered responses). Managers described it in the following terms:

- "Most work is manual. Women are considered not physically fit for the job or work" and 
- "The administrative side of the business is where females are preferred. The production side is where males are more suitable because of the manual labour involved."

This result may be a function of the sample, but this matter will be addressed in the discussion section of the article. The second most frequently volunteered theme was placement of employees, with $25 \%$ of the statements relating to this aspect, for example:

- "During the placement step, careful consideration is given to pregnant women; for safety and health reasons they cannot be placed underground" and

- "There is discrimination against women in the allocation of jobs."

Both themes suggest gender-based job segregation, and gender-based discrimination against females.

Following the open-ended question, managers were given a chart depicting a generic appointment process, and asked, "Does discrimination against women occur during any of these steps?" This is also reported in Table 1, in the column marked "endorsed themes". It can be observed from Table 1 that the decisions that follow interviews were most frequently identified as the point where discrimination occurs in the appointment process, with $28 \%$ of the endorsements. The second most important area was the screening of applicants, with $19 \%$. It can be noted that when managers were confronted with specific human resource themes, different themes emerged. A reason for this may be the fact that a large percentage of the respondents were operational managers, who are not au fait with human resource processes and the jargon of the discipline.

As stated in the methodology section, managers were also asked, "Are there, any formal policies in this organisation that suggest that women should be given preferential treatment with regard to appointments in the organisation?" In total 17 respondents (23\% of all managers) indicated that this does indeed occur. In the last question pertaining to appointments, managers were asked, "Are there any unwritten instructions in this organisation that suggest that women should be given preferential treatment with regard to appointments in the organisation?" Twenty-one managers $(28 \%$ of all managers) indicated that preferential treatment occurs.

\subsection{Promotions}

The findings indicate that 29 (39\%) of the 75 managers interviewed gave an affirmative answer to the question on gender-based discrimination during promotions. Out of the 29 statements explaining the nature of the discrimination, 18 corresponded to the preset themes. The balance of the statements (11) focused on broad organisational and national cultural aspects. Examples of these statements were:

- "There is talk of bringing ladies into senior positions" and

- "This is done in order to address past discriminatory practices whereby women were not appointed to senior positions or for underground work."

The rest of the statements were categorised according to the set categories and the inter-observer reliability was .88. The findings are presented in Table 2.

The most frequently volunteered theme was discrimination during the decisions that follow interviews ( $28 \%$ of all responses). The following are examples of how managers described this:

- "At times, even when a man outperformed a woman, the panel ... can recommend the appointment of an appointable woman" and 
- "If two candidates have equal capabilities, the female candidate will be given preferential consideration."

Table 2

Areas of discrimination against women in the promotion process

\begin{tabular}{|c|c|c|c|c|}
\hline \multirow[b]{2}{*}{ Themes } & \multicolumn{2}{|c|}{ Volunteered responses } & \multicolumn{2}{|c|}{ Endorsed themes } \\
\hline & Count $^{\#}$ & $\begin{array}{c}\text { Relative } \\
\text { frequency }\end{array}$ & Count & $\begin{array}{c}\text { Relative } \\
\text { frequency }\end{array}$ \\
\hline Job analysis/post description & $.5 ; 1 ; 1.5$ & .18 & 4 & .06 \\
\hline Access development and training & $1 ; 1$ & .11 & 9 & .14 \\
\hline Performance appraisals & 1 & .06 & 4 & .06 \\
\hline Advertising of post & 1 & .06 & 7 & .11 \\
\hline Screening of applicants & $1 ; 1 ; 1 ; .5 ; 1$ & .25 & 16 & .25 \\
\hline Interviews with applicants & $1 ; .5$ & .08 & 6 & .16 \\
\hline Decisions following interview & $1 ; 1 ; 1 ; 1 ; 1$ & .28 & 11 & .17 \\
\hline Salary offers & & & 5 & .08 \\
\hline Induction of employees & & & 1 & .02 \\
\hline Total & 18 & 1 & 63 & 1 \\
\hline
\end{tabular}

${ }^{\#}$ A score of .5 indicates that one observer selected the theme while the other person favoured a different theme. A score of 1 indicates that the observers were in agreement with the allocation of the themes.

The second most frequently volunteered theme concerned the screening of the applicants (25\% of all responses). Examples are:

- "The set criteria during shortlisting favour women, as they score more marks than men" and

- "Women will be scored 10 points above men, just for being women. This is the implementation of the equity plan of ..."

Following this, managers were given a chart depicting a generic promotion process and asked to point out where discrimination against women was most likely to occur. The screening of the applicants was most frequently (25\% of all responses) pointed out as the place where discrimination occurs in the promotion process. The second most important area was the decisions that follow the interview (17\% of all responses). These two themes were also the top two themes volunteered. It therefore appears that females are given preferential treatment when it comes to promotions.

With regard to the existence of formal policies that allow women to be afforded preferential treatment with regard to promotions, 13 managers (17\% of all managers) indicated that this was the case. With regard to informal or unwritten instructions, 9 managers $(12 \%$ of all managers) professed that this was the case in their respective organisations.

\subsection{Remuneration}

In all, $12(16 \%)$ of the 75 managers interviewed answered in the affirmative to a question related to gender-based discrimination with regard to remuneration. It was possible to categorise 12 of the 13 statements explaining discrimination at remuneration level. The statement that was not analysed was: "Promotion is usually considered at the lower level" and this did not seem relevant. It was possible to categorise the rest of the items, and the inter-observer reliability for the statements that were categorised was 1.0. 
Table 3

Managers endorsing discrimination against women regarding remuneration

\begin{tabular}{|l|c|c|c|c|}
\hline \multicolumn{1}{|c|}{ Themes } & \multicolumn{2}{|c|}{ Volunteered responses } & \multicolumn{2}{c|}{ Endorsed themes } \\
\hline Job analysis & Count & $\begin{array}{c}\text { Relative } \\
\text { frequency }\end{array}$ & Count & $\begin{array}{c}\text { Relative } \\
\text { frequency }\end{array}$ \\
\hline Job evaluation & & & 2 & .12 \\
\hline Pay structuring & & & & \\
\hline Performance appraisals & $1 ; 1 ; 1 ; 1 ; 1 ; 1 ; 1$ & .58 & 3 & .18 \\
\hline Decision-making practices & $1 ; 1 ; 1$ & .25 & 5 & .29 \\
\hline Total & $1 ; 1$ & .17 & 7 & .41 \\
\hline
\end{tabular}

The most frequently volunteered theme, identified in more than $50 \%$ of the responses, was discrimination during the pay-structuring process, and managers described this as follows:

- "Males do earn more than females at the same level of management within the organisation" and

- "On basic salaries, women earn less."

The second most frequently volunteered theme was discrimination during performance appraisals, with examples such as:

- "There are too many women in decision-making positions who favour their kith and kin [sic]" and

- "The trend in (the) performance management process indicates men are usually rated higher than women, which allows them to receive higher salary increases than women."

Following the open-ended question, managers were given a chart depicting a generic remuneration process, and asked, "Does discrimination against women occur during any of these steps?" This is reported in Table 3, in the column marked "endorsed themes". From Table 3, it can be observed that decision-making practices were most frequently pointed out as the place where discrimination occurs in the remuneration process. The second most important area was performance appraisals. From the type of responses received, it seems as though discrimination against females occurs during the remuneration process.

Not a single respondent indicated that formal policies in their places of work suggested that women should be given preferential treatment with regard to remuneration and only two managers (3\% of all managers) indicated that this occurs informally or outside of formal instructions.

\section{Discussion and conclusions}

In this research, information was gathered from managers who reported on relatively large groups of employees. The size of these groups (60 per organisation) made it very unlikely that they were representative of top managers or middle managers. Those reported on were therefore most likely to be supervisors and general employees at operational level. This reasoning was supported by statements made during the interviews that suggested that the work was at a low organisational level and might require physical strength or basic administrative skills. Focusing on lower-level employees contributes to the body of knowledge as many previous reports on gender discrimination focused primarily on senior employees (e.g. April et al 2007; Booysen 
2007; Johnson \& Mathur-Helm 2011; Msweli-Mbanga, Fitzgerald \& Mkhize 2005; Zulu 2003).

It is also important to note that data were collected from 75 managers. Although this was a convenience sample of managers from mining (33\%), the services industry $(27 \%)$, government $(27 \%)$, and small manufacturing $(13 \%)$, it represented a comparatively large number of respondents and a broad selection of managers, unlike several other studies that focused on specific industries (e.g. Boshoff 2005; Kahn 2008; Kane-Berman \& Hickman 2003; Lloyd \& Mey 2007; Montesh 2010). In addition to the South African study by Thomas (2003), which was conducted across several organisations, this article makes a significant contribution to knowledge about genderbased discrimination in South Africa as it integrates data from a broad base of South African companies.

Another important feature of this study is that managers reported on the discriminatory practices in which they had been involved, and not on discrimination experienced by them or practised against them. Having managers as respondents, reporting on employees, may have provided a clearer picture of the real situation, as they (the managers) could have been less affected by in-group bias than respondents who are directly affected by discrimination as a result of their group membership (Tajfel 1981).

The quality of the analysis of the responses, as reflected in the inter-observer reliability coefficient, was acceptable on average. The individual values were $.80(\mathrm{~N}=$ 20), $.88(\mathrm{~N}=18)$ and $1(\mathrm{~N}=12)$. The average was $.88(\mathrm{~N}=50)$, which is higher than the minimum value suggested by Shaughnessy et al (2009).

From the findings it is clear that gender-based discrimination occurs mostly at promotional level (39\% of managers reported this), less at appointment level $(32 \%$ of managers reported this), and least during the determination of remuneration $(16 \%$ managers reported this). With regard to promotions, pro-female discrimination appeared to occur most frequently. This preferential treatment occurs during the screening phase and when decisions are made after interviewing. This was evident from both the volunteered and the endorsed themes. In addition to the findings suggested by the literature, it was found that discrimination seems to be driven by a culture that favours the promotion of women as well as by the applicable legislation and charters.

When gender-based discrimination at appointment level is examined, it appears that discrimination often occurs in favour of men. When volunteered responses by the managers were analysed, it became evident that this occurred at the job analysis/job description stage and during the placement of employees. This should be seen within the context of the fact that many of the managers were reporting on jobs that required physical labour (mining/manufacturing), and that a certain amount of job segregation traditionally occurs along gender lines (Munroe \& Munroe 1975) in such positions. When managers were confronted with a list of human resource practices that might affect gender discrimination during appointments, the decision-making practices that followed interviews were most frequently listed in this research.

With regard to the determination of remuneration, men seem to be at an advantage. The unstructured responses of the managers were coded as indicative of discrimination in (individual) pay structuring. This could be seen within the context of performance management, where men seem to outscore women. Men may be at an advantage when it comes to performance assessments, as they are generally less involved with family matters (Cascio 2010) and may spend more time at work (Scott \& McClellan 
1990). Weak evidence that suggests that differences in income between females and males vary in accordance with the gender composition of senior partners (in the medical facility at their organisation) is provided by Gravelle, Hole and Santos (2011). Hultin and Szulkin (1999) argue along the same lines and suggest that earnings are affected by the gender composition of managerial and supervisory staff. Theoretical arguments focus on managers' propensity to create and maintain or to undermine institutionalised gender bias and employees' capacity to mobilise resources and establish claims in the wage distribution process, mainly through social networks. Results show that gender-differentiated access to organisational power structures plays an essential part in explaining women's relatively low wages. Women who work in establishments in which relatively many of the managers are men earn lower wages than women with similar qualifications and job demands in establishments with more women in the power structure (Hultin \& Szulkin 1999).

With regard to the structured responses, the managers emphasised decision-making practices that result in remuneration differences. If the work environment is dominated by men, this would put them at an advantage when decisions are made (Naidu 1997; Stone \& Stone-Romero 2006). However, women also hold powerful positions in the workplace, and use these positions to discriminate against others, including women (Johnson \& Marthur-Helm 2011).

The above resonates well with critical theory and Marxist thinking, and the fact that managers use their power in decision-making situations to maintain the status quo, which, as reported in this research, gives rise to distrust in managerial ability to effect a fair society. Cascio and Aguinis (2011) state very clearly that decisions should be made mechanically, using mathematical models, rather than being based on judgement, as managers do not have the cognitive ability to integrate the large amount of information that needs to be considered when making decisions.

The reports of managers regarding formal and informal policies that advocate gender-based discrimination showed that policies are more often in place at appointment, less often at promotion and even less often at the remuneration level. Few managers report formalised discrimination at appointment level $(23 \%)$ and even fewer report it at promotion level (17\%). This is strange as the Employment Equity Act of 1998 prescribes affirmative action during appointments and promotions. This may suggest that legislation is not always formalised in company policies. It was refreshing to note that not a single manager indicated that formal policies guide discrimination at the remuneration level. Informal or unwritten policies regarding gender-based discrimination followed the same pattern as formal policies, in that they were the highest at appointment level and the lowest at remuneration level.

To conclude, most gender-based discrimination occurs during promotions, and this is generally pro-female discrimination. Pro-male discrimination occurs at appointment level and is often due to the inherent requirements of the job and as such may be considered to be fair discrimination. Lastly, some gender-based discrimination occurs at remuneration level, where men seem to be at an advantage, receiving higher salaries than women at the same organisational level. This discrimination occurs during structured human resource processes (e.g. in job descriptions - at appointments) as well as during less structured processes (e.g. decision-making after interviews - at promotions). The reports of managers therefore indicate that gender-based discrimination is not a one-sided affair and both parties are at the receiving end, depending on the process involved. 
The findings of this research should make practitioners aware of the areas where gender-based discrimination occurs, as well as of the fact that it is not only directed at a particular gender group. Practitioners should also take note that discrimination occurs in the structured as well as the less structured processes. Practitioners therefore need to design and implement human resource management tools that would allow the structured processes to be gender-blind. This could include convening more diverse decision-making panels, as this could facilitate more equitable decisions (DeGrassi, Morgan, Walker, Yingchun \& Sabat 2012; Martin-Alcazar, Romero-Fernandez \& Sanchez-Gardey 2012). Diverse panels could also have a positive influence on the less structured, often informal processes, where decisions are made. Furthermore, managers do not always seem to be aware of the formal policies that should guide decision-making, and training in this respect may be necessary. In this regard human resource practitioners should take the lead and make sure that all stakeholders know and apply the policies.

The study had some limitations. There may have been some testing effects (Kerlinger \& Lee 2000), as can be seen from general question 1 and general question 2. It could be argued that once managers became aware of some of the human resource terminologies, they started using them. It should be possible to control for this effect by alternating the sequence of the questions posed, and this may be a recommendation for future research of this nature. Another possible limitation is that the gender of the managers was not asked for or recorded. This is a limitation as ingroup bias plays an important role when evaluating other groups (Tajfel 1981). This element was, however, not introduced in the study as small groups of managers were interviewed per organisation, and this was seen as a way to protect their anonymity. This could be addressed in future studies if more managers per organisation participate. A further limitation was the possible need of the respondents to answer questions in a politically correct manner and to hide the true nature of the discrimination that does exist. It would be naïve to expect that, as is the case with modern racism, blatant sexism would be publicly displayed Swim, Aikin, Hall \& Hunter 1995). This could explain the bottoming effect witnessed in a number of reports on discrimination. This limitation of low report rates could be addressed by using questionnaires that have been designed and administered in such a way as to ensure anonymity. A further limitation was the use of convenience sampling. This does not allow for broad generalisations (Rosnow \& Rosenthal 2008). This could be addressed through random sampling. Lastly, this research is limited by its focus on only three human resource processes, namely appointments, promotions and remuneration. Future researchers could expand the scope of their study and focus on a broader range of practises, including elements such as access to training and development as well as performance management, to mention only two.

\section{List of references}

Anon. 2012. Weaknesses in South Africa's progress with women's equality and the Millennium Development Goals. Agenda: Empowering Women for Gender Equity 26(1):91-103.

April, K, Dreyer, S \& Blass, E. 2007. Gender impediments to the South African executive boardroom. South African Journal of Labour Relations 31(2):51-67.

Armstrong, M. 2009. Handbook of human resources practices. $11^{\text {th }}$ edition. London: Kogan Page. 
Baron, RA, Branscombe, NR \& Byrne, D. 2009. Social psychology. $12^{\text {th }}$ edition. Boston, MA: Pearson/Allyn \& Bacon.

Barry, H, Child, I \& Bacon, M. 1959. Relation of child training to subsistence economy. American Anthropologist 61:51-63.

Basim, HN, Sesen, H \& Sesen, E. 2007. Are they equal? Comparison of Turkish and English job announcements in terms of some discrimination factors. Humanity Social Sciences Journal 2(1):34-42. Available at: http://idosi.org/hssj/hssj2 (1)07/6.pdf (accessed on 3 March 2012).

Bezuidenhout, MC, Garbers, CJ \& Potgieter, S. 2007. Managing for healthy labour relations: A practical guide for health services in Southern Africa. Pretoria: Van Schaik.

Bohlander, GW \& Snell, SA. 2013. Principles of human resource management. $16^{\text {th }}$ edition. New York, NY: South-Western Cengage Learning.

Booysen, L. 2007. Barriers to employment equity implementation in and retention of blacks in management in South Africa. South African Journal of Labour Relations 31(1):47-51.

Boshoff, N. 2005. The representation of women academics in higher education in South Africa: Progress in the pipeline? South African Journal of Higher Education 19(2):359-377.

Bradley, H \& Healy, G. 2008. Ethnicity and gender at work: Inequalities, careers and employment relations. London: Palgrave.

Burke, RJ \& Vinnicombe, S. 2005. Advancing women's careers. Career Development International 10:165-7.

Cascio, WF \& Aguinis, H. 2011. Applied psychology in human resource management. $7^{\text {th }}$ edition. Upper Saddle River, NJ: Pearson.

Cascio, WF. 2010. Managing human resources: Productivity, quality of work life, profits. $8^{\text {th }}$ edition. New York, NY: McGraw-Hill.

Channer, ZA, Abbassi, Z \& Ujan IA. 2011. Gender discrimination in workforce and its impact on the employees. Pakistan Journal of Commerce and Social Sciences 5(1):177-191.

Dessler, G. 2011. Human resource management. $12^{\text {th }}$ edition. Upper Saddle River, NJ: Prentice Hall.

DeGrassi, SW, Morgan, WB, Walker, SS, Yingchun, IW \& Sabat, I. 2012. Ethical decision-making: Group diversity holds the key. Journal of Leadership, Accountability \& Ethics 9(6):51-65.

Employment Equity Commission. 2013. Employment Equity Commission Annual Report 2012-2013. Pretoria: Department of Labour. Available at: http://us-cdn. creamermedia.co.za/assets/articles/attachments/44272_cee13report.pdf (accessed on 9 December 2013).

Fisher, CD, Schoenfeldt, LF \& Shaw, JB. 2006. Human resource management. $6^{\text {th }}$ edition. Boston, MA: Houghton Mifflin.

Floro, MS \& Komatsu, H. 2011. Gender and work in South Africa: What can time-use data reveal? Feminist Economics 17(4):33-66.

Frame, MC, Roberto, KJ, Schwab, AE \& Harris, CT. 2010. What is important on the job? Differences across gender, perspective and job level. Journal of Applied Social Psychology 40(1):36-56. 
Frost, N. 2011. Qualitative research methods in psychology: Combining core approaches. Birkshire: Open University Press.

Gandhi, P. 2010. Gender discrimination in the workplace. Available at: http://www.scribd.com/doc/22571816/Gender-Discrimination-in-Work-Place (accessed on 25 June 2013).

Glesne, C. 2011. Becoming qualitative researchers: An introduction. $4^{\text {th }}$ edition. Boston, MA: Pearson.

Gómez-Mejía, LR, Balkin, DB \& Cardy, RL. 2007. Managing human resources. $5^{\text {th }}$ edition. Upper Saddle River, NJ: Pearson/Prentice Hall.

Good, JJ \& Rudman, A. 2009. When female applicants meet sexist interviewers: The costs of being a target of benevolent sexism. Sex Roles 62:41-493.

Gravelle, H, Hole, AR \& Santos, R. 2011. Measuring and testing for gender discrimination in physician pay: English family doctors. Journal of Health Economics 30(4):660-674.

Grobler, P, Wärnich, S, Carrell, MR, Elbert, NF \& Hatfield, RD. 2011. Human resource management in South Africa. $4^{\text {th }}$ edition. London: Thomson Learning.

Grogan, J. 2007. Dismissal, discrimination and unfair labour practices. $2^{\text {nd }}$ edition. Cape Town: Juta.

Grun, C. 2004. Direct and indirect gender discrimination in the South African labour market. International Journal of Manpower 25(3):321-342.

Hareli, S, Klang, M \& Hess, U. 2008. The role of career history in gender based biases in job selection decisions. Career Development International 13(3):252-269.

Hinks, T. 2002. Gender wage differentials and discrimination in the New South Africa. Applied Economics 34(16):2043-2052.

Hultin, M \& Szulkin, R. 1999. Wages and unequal access to organizational power: An empirical test of gender discrimination. Administrative Science Quarterly 44(3):453-472.

Ivancevich, JM. 2010. Human resource management. $11^{\text {th }}$ edition. New York, NY: McGraw- Hill.

Johnson, Z \& Mathur-Helm, B. 2011. Experiences with queen bees: A South African study exploring the reluctance of women executives to promote other women in the workplace. South African Journal of Business Management 42(4):47-55.

Kahn, SB. 2008. Employment of women in the South African National Defence Force: 1998-2008. Journal of Public Administration 44(1):197-208.

Kane-Berman, J \& Hickman, R. 2003. Women doctors in medical professional organisations in South Africa: A report by the Women in Medicine Workgroup. South African Medical Journal 93(1):69-73.

Karsten, MF. 2006. Race and ethnicity in the workplace: Issues and challenges for today's organisations. Westport, CT: Praeger.

Kerlinger, FN \& Lee, HB. 2000. Foundations of behavioural research. $4^{\text {th }}$ edition. Forth Worth, TX: Harcourt College Publishers.

Konrad, AM, Ritchie, JE, Lieb, P \& Corrigall, E. 2000. Sex differences and similarities in job attribute preferences: A meta-analysis. Psychological Bulletin 126:593-641.

Lim, GS, Mathis, RL \& Jackson, JH. 2010. Human resources management. Singapore: Cengage. 
Lloyd, HR \& Mey, MR. 2007. Gender differences in perceptions of workplace progression: An automotive industry case study. Southern African Business Review 11(3):95-120.

Martin-Alcazar, F, Romero-Fernandez, P \& Sanchez-Gardey, G. (2012). Effects of diversity on group decision-making processes: The moderating role of human resource management. Group Decision \& Negotiation 21(5):677-701.

Mathis, RL \& Jackson, JH. 2003. Human resource management. $10^{\text {th }}$ edition. Mason, $\mathrm{OH}$ : South-Western.

Mathur-Helm, B. 2005. Equal opportunity and affirmative action for South African women: A benefit or barrier? Gender in Management 20(1/2):56-71.

Mathur-Helm, B. 2006. Woman and the glass ceiling in South African banks: An illusion or a reality. Women in Management Review 21(4):311-326.

Meiring, D, Van de Vijver, AJR, Rothman, S \& Barrick, MR. 2005. Construct, item, and method bias of cognitive and personality measures in South Africa. South African Journal of Industrial Psychology 31(1):1-8.

Mello, D \& Phago, K. 2007. Affirming women in managerial positions in the South African public service. South African Journal for Political Science and Public Administration 26(2):145-158.

Metcalf, H \& Rolfe, H. 2009. Employment and earnings in the finance sector: A gender analysis. Manchester: National Institute of Economic and Social Research. Available at: http://www.equalityhumanrights.com/uploaded_files/download_ finance_gender_analyis_research.pdf (accessed on 25 June 2013).

Mondy, WR. 2012. Human resource management. $12^{\text {th }}$ edition. Essex: Pearson.

Montesh, M. 2010. Transformation in the South African Police Service: The implementation of affirmative action and employment equity in SAPS. South African Journal of Criminal Justice 23(1):55-77.

Msweli-Mbanga, P, Fitzgerald, P \& Mkhize, A. 2005. Representation of women directors in JSE securities exchange listed companies: Institutional theory perspective. South African Journal of Labour Relations 29(1):98-110.

Munroe, RL \& Munroe, RH. 1975. Cross-cultural human development. Monterey, CA: Brooks/Cole.

Naidu, KM. 1997. Indirect discrimination against women in the workplace. Master's thesis, University of Natal.

Ncayiyana, DJ. 2011. Feminisation of the South African medical profession: Not yet nirvana for gender equity. South African Medical Journal 101(1):5.

Nel, PS, Van Dyk, PS, Haasbroek, GD, Schultz, HB, Sono, T \& Werner, A. 2008. Human resources management. $7^{\text {th }}$ edition. Cape Town: Oxford University Press.

Niemann, R. 2002. Redress and empowerment for gender equity in South African education. Acta Academica 3(1):167-195.

Noe, RA, Hollenbeck, JR, Gergart, B \& Wright, PM. 2008. Human resource management: Gaining a competitive advantage. $6^{\text {th }}$ edition. Boston, MA: McGrawHill Irwin.

Ocon, R. 2006. Gender and diversity in management. New York, NY: University Press of America.

Pfeffer, J. 1994. Competitive advantage through people. Boston, MA: Harvard Business School Press. 
Pfeffer, J. 1995. Producing sustainable competitive advantage through effective management of people. Academy of Management Executive 9:55-69.

Pfeffer, J. 1998. The human equation: Building profits by putting people first. Boston, MA: Harvard Business School Press.

Pratto, F. 1996. Sexual politics: The gender gap in the bedroom, the cupboard and the cabinet. In DM Buss \& NM Malamuth (Eds). Sex, power, conflict: Evolutionary and feminist perspectives. New York, NY: Oxford University Press.

Pretorius, E, De Villiers Human, S, Niemann, R, Klinck, E \& Alt, H. 2002. Fighting from within: Gender equity at the University of the Free State. Acta Academica 3(1):1-38.

Republic of South Africa. 1995. Labour Relations Act 66 of 1995. Available at: http://www.info.gov.za/acts/1995/a66-95.pdf (accessed on 7 March 2012).

Republic of South Africa. 1996. Constitution of South Africa. Available at: http://www.info.gov.za/documents/constitution/1996/a108-96.pdf (accessed on 7 March 2012).

Republic of South Africa. 1997. Basic Conditions of Employment Act 75 of 1997 Available at: http://www.labour.gov.za/DOL/downloads/legislation/acts/basicconditions-of-employment/Act $\% 20-\% 20$ Basic $\% 20$ Conditions $\% 20$ of $\% 20$ Employment.pdf (accessed on 20 October 2014).

Republic of South Africa. 1998. Employment Equity Act 55 of 1998. Available at: https://www.labour.gov.za/downloads/legislation/acts/employment-equity/Act\%20\%20Employment\%20Equity.pdf (accessed on 7 March 2012).

Republic of South Africa. 2000. Promotion of Equality and Prevention of Unfair Discrimination Act 4 of 2000. Available at: http://www.justice.gov.za/legislation/ acts/2000-004.pdf (accessed on 7 March 2012).

Republic of South Africa. 2013. Women Empowerment and Gender Equality Bill. Available at: http://www.parliament.gov.za/live/commonrepository/Processed/ 20131108/553400_1.pdf (accessed on 9 December 2013).

Rosnow, RL \& Rosenthal, R. 2008. Beginning behavioural research: A conceptual primer. $6^{\text {th }}$ edition. Upper Saddle River, NJ: Pearson/Prentice Hall.

Rossi, AS \& Rossi, HP. 1990. Of human bonding: Parent-child relations across the life course. Hawthorne, NY: Aldine de Gruyter.

Schwartz, SH \& Rubel, T. 2005. Sex differences in value priorities: Cross-cultural and multimethod studies. Journal of Personality and Social Psychology 89:1010-1028.

Scott, KD \& McClellan, EL. 1990. Gender differences in absenteeism. Public Personnel Management 19(2):229-253.

Serumaga-Zake, PAE \& Naudé, WA. 2003. Labour market discrimination in the North West province of South Africa. Development Southern Africa 18(5):671-682.

Shaughnessy, JJ, Zechmeister, EB \& Zechmeister, JS. 2009. Research methods in psychology. $8^{\text {th }}$ edition. New York, NY: McGraw-Hill.

Slonim, R. 2004. Gender selection discrimination: Evidence from a Trust Game. Cleveland, $\mathrm{OH}$ : Case Western Reserve University. Available at: https://aeaweb.org/ assa/2005/0108_0800_1302.pdf (accessed on 24 June 2013).

Stone, D \& Stone-Romero, E. 2006. Unbiased hiring systems. In J Greenhaus \& G Callanan (Eds). Encyclopedia of career development. Thousand Oaks, CA: SAGE Publications. 
Stone, K \& Coetzee, M. 2005. Levelling the playing field: Reducing barriers to mentoring for women protégés in the South African organisational context. $S A$ Journal of Human Resource Management 3(3):33-39.

Stredwick, J. 2005. An introduction to human resources management. $2^{\text {nd }}$ edition. Burlington, MA: Elsevier.

Swanepoel, BJ, Erasmus, BJ \& Schenk, HJ. 2008. South African human resource management theory and practice. $4^{\text {th }}$ edition. Cape Town: Juta.

Swim, JK, Aikin, KJ, Hall, WS \& Hunter, BA. 1995. Sexism and racism: Old-fashioned and modern prejudices. Journal of Personality and Social Psychology 68:199-214.

Tajfel, H. 1981. Human groups and social categories: Studies in social psychology. London: Cambridge University Press.

Tamres, LK, Janicki, D \& Helgenson, VS. 2002. Sex differences in coping behavior: A meta-analytical review and an examination of relative coping. Personality and Social Psychology Review 6:2-30.

Taylor, SE. 2002. The tending instinct: How nurturing is essential to who we are and how we live. New York, NY: Times Books/Henry Holt.

Terre Blanche, M, Durrheim, K \& Painter, D. 2009. Research in practice. $2^{\text {nd }}$ edition. Cape Town: UCT Press.

Thomas, A. 2003. Employment equity practices at selected companies in South Africa. South African Journal of Labour Relations 27(3\&4):6-40.

Walters, IS \& Le Roux, NJ. 2008. Monitoring gender remuneration inequalities in academia using biplots. ORION 24(1):49-73.

Welle, B \& Heilman, ME. 2005. Formal and informal discrimination against women at work. West Point, NY: Information Age Publishers.

Yukl, G. 2010. Leadership in organisations. $7^{\text {th }}$ edition. Thousand Oaks, CA: Pearson /Prentice Hall.

Zulu, C. 2003. Gender representation patterns in higher education management in South Africa: Perspectives on higher education. South African Journal of Higher Education 17(1):98-104. 